\title{
Implementation of Web-Based Client Outreach Activity Data Processing Systems at Bina Muda Gemilang Foundation
}

\author{
Sri Rahayu* ${ }^{*}$, Po Abas Sunarya ${ }^{2}$, Salsabillah Devia Khansa ${ }^{3}$ \\ ${ }^{1,2,3}$ Fakultas Sains \& Technology University of Raharja \\ E-mail: ${ }^{1}$ sri.rahavu@ raharja.info,${ }^{2}$ abas@ raharja.info,${ }^{3}$ salsabillah.devia@ raharja.info
}

\begin{abstract}
In the current era where technology is increasingly developing so that it can change a pattern or habit of society, it can be used by anyone, anywhere. The Bina Muda Gemilang Foundation is no exception, which also takes advantage of technological developments to increase the efficiency and effectiveness of existing business processes. One of the business processes that run at this foundation, namely the data processing of client outreach activities, there are still many gaps where the error rate of data input is quite high. Also frequent date falsification of outreach activities and officer indiscipline in data input. This study aims to solve existing problems by creating a web-based system that is made using the programming languages PHP and MySQL for the database, which can facilitate business processes and minimize errors.
\end{abstract}

Keywords - Business processes, HIV/AIDS, Web, PHP, MySQL

\section{INTRODUCTION}

The Bina Muda Gemilang Foundation is a foundation that is engaged in the issue of HIV / AIDS Prevention \& Control which reaches Kabupaten Lebak, Kabupaten Pandeglang, Kabupaten Serang, Kabupaten Tangerang, Kota Cilegonand Kota Serang. In addition, the Bina Muda Gemilang Foundation is also a center for HIV / AIDS and STI counseling and information services. So it is his duty to educate the community who is the target of the reach or what is known as the KP. The key population at this foundation is MSM (men sex with men), Waria (male women), IDU (injecting drug users) and FSW (female sex workers). And it is from the key populations that are reached who become clients at the Bina Muda Gemilang Foundation.

The task of reaching and referring these key populations are field officers (PL) and peer educators (PE). The outreach process at this foundation is a process where field officers (PL) approach MARPs to obtain information about client identities such as name, date of birth, sexual orientation and other information. The reason these four key populations are reached is because they have a high risk of contracting HIV / AIDS, and are also at high risk of contracting and transmitting to other people. The aim of this outreach is to educate about HIV / AIDS so that they understand about transmission and how to prevent it. As well as providing prevention packages in the form of IEC (Communication, Information and Education), condoms and lubricants. And referrals are invitations made by PL and PE to clients to do VCT (Voluntary Counseling and Testing) tests to community health centers or regional hospitals either statically (coming directly to services) or mobile (service officers go directly to the field) .

After field officers and peer educators carry out outreach and referrals, they will write outreach reports in the form of daily outreach forms, client profiles, TB screening and referrals to Google Forms to be reported to the Field Coordinator (KL) and monev. However, here there are several problems in the outreach data input process, including many errors in 
inputting to delays in data input that can hinder other business processes. Therefore, this research implements a web-based application system that can overcome existing problems and minimize the emergence of new problems.

\section{RESEARCH METHOD}

\subsection{Data collection methods}

In research conducted at the Bina Muda Gemilang Foundation in data collection for system design using several methods:

\subsubsection{Observation}

Researchers have made observations at the Bina Muda Gemilang Foundation to collect data and information, analyze input and output and what tools are used by field officers, peer educators, field coordinators and monev staff.

\subsubsection{Interview}

The author conducted interviews with monev staff at the Bina Muda Gemilang Foundation as stakeholders to find out which system was running, the tools used, field conditions and other information to support this research.

\subsubsection{Literature Study}

To support the research, the author looks for sources from books, journals and websites related to the problem, as well as guidelines and references in this study.

\subsection{Data Analysis Method}

This study uses the UML (Unified Modeling Language) design to describe the outreach data processing system which is described by use cases and activity diagrams for depicting systems, and class diagrams for depicting interactions between objects.

\subsection{Literature Review}

\subsubsection{System}

According to Hutahaean, the system is a set of procedures that form a network that is interconnected and works together to carry out an activity in order to achieve a certain goal ${ }^{[1]}$. This system has a very broad meaning because the word "system" is used in many aspects, starting from the aspects of politics, education, technology and science, even in everyday life.

\subsubsection{System Analysis}

Stated by Suryadi. (2016: 270), who said that system analysis is the decomposition of the origin of a complete system into its component parts with the aim of identifying and evaluating problems, constraints that occur from the expected needs so that a the fix ${ }^{[2]}$.

\subsubsection{Data}

In the opinion of Martono, Kartika, Putri Aullia, (2017: 231) in the CCIT Journal, Vol 10 No. 2, argues that data is a description of objects, events, activities and transactions, which have no meaning or have no direct effect on the user ${ }^{[3]}$.

\subsubsection{Website}

According to Dewi Immaniar and Achmad Rizal Kurniawan (2018), "Website (WEB) is an internet facility that connects documents both locally and remotely. Documents on the website are called web pages and the links on the website allow users to move from one page 
to another (hyper text), both between pages stored on the same server and servers around the world "[4].

\subsubsection{PHP}

PHP stands for: Hypertext Preprocessor. However, the original stands for Personal Home Page which is a server side programming language designed for web development, as well as being used for general purposes ${ }^{[5]}$.

\subsubsection{MySQL}

SQL stands for Structured Query Language. MySQL is a Database Relational Database Management System (RDBMS) which is a popular database for use in web applications ${ }^{[5]}$.

\section{RESULTS AND DISCUSSION}

Based on observations, problems often occur in the data input and evaluation process due to human error factors, the mismatch of the system used and the discipline of officers. Therefore, this study has three main objectives, namely minimizing the rate of data input errors due to human errors, making systems more suitable for existing business processes and systems that can improve officer discipline. In addition to solving the above problems, in making this system, efficiency and effectiveness are also needed in its use to make it easier for officers and save more time and energy.

This system is created and implemented on a web-based basis because it is considered more practical and can be used multi devices. The web is created using the PHP programming language for the backend. HTML, CSS and Javascript for the frontend and MySQL for the database. After that, the project will be hosted so that the web can be used online by all officers by accessing the y foundationbmg.com link in their respective browsers. On the web, there is one login page for all officers, both field officers, field coordinators and monev. After logging in, the page will automatically lead to the dashboard page according to the access code so that the web page display can be adjusted to the job desk officer.

On this website, officers can not only input outreach data, but officers can also do attendance for monitoring daily activities, export data logbooks to pull data from all clients, monthly narrative to report monthly activities and admin contacts to send messages to the web admin. and monitoring and evaluation if there are obstacles. For more details, see the UML design to describe the system on the foundationbmg.com website. 


\subsection{UML Design}

\subsubsection{Use Case Diagram}

\subsubsection{Use Case Field Officer (PL)}

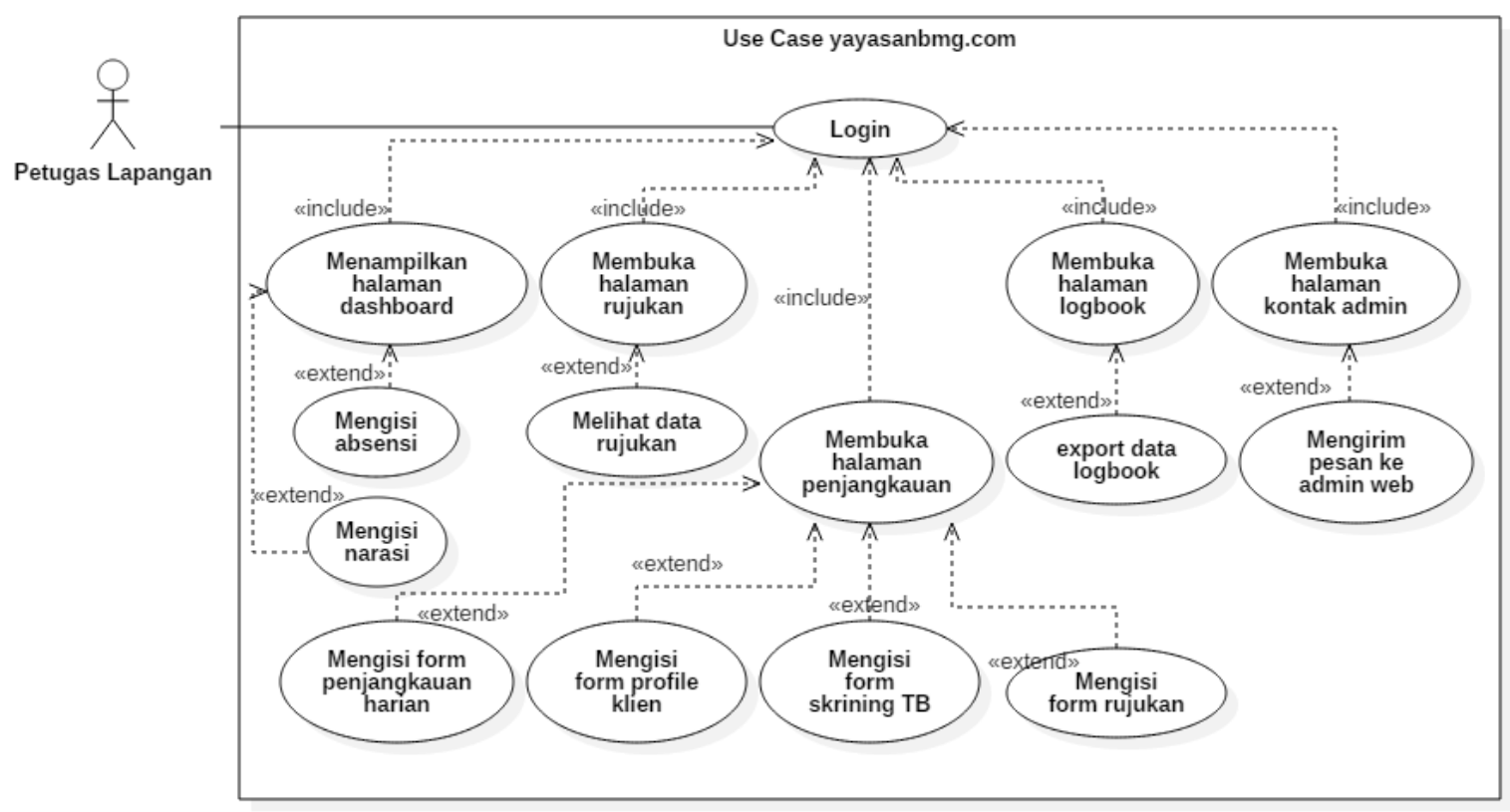

\subsubsection{Use Case Field Coordinator (KL)}

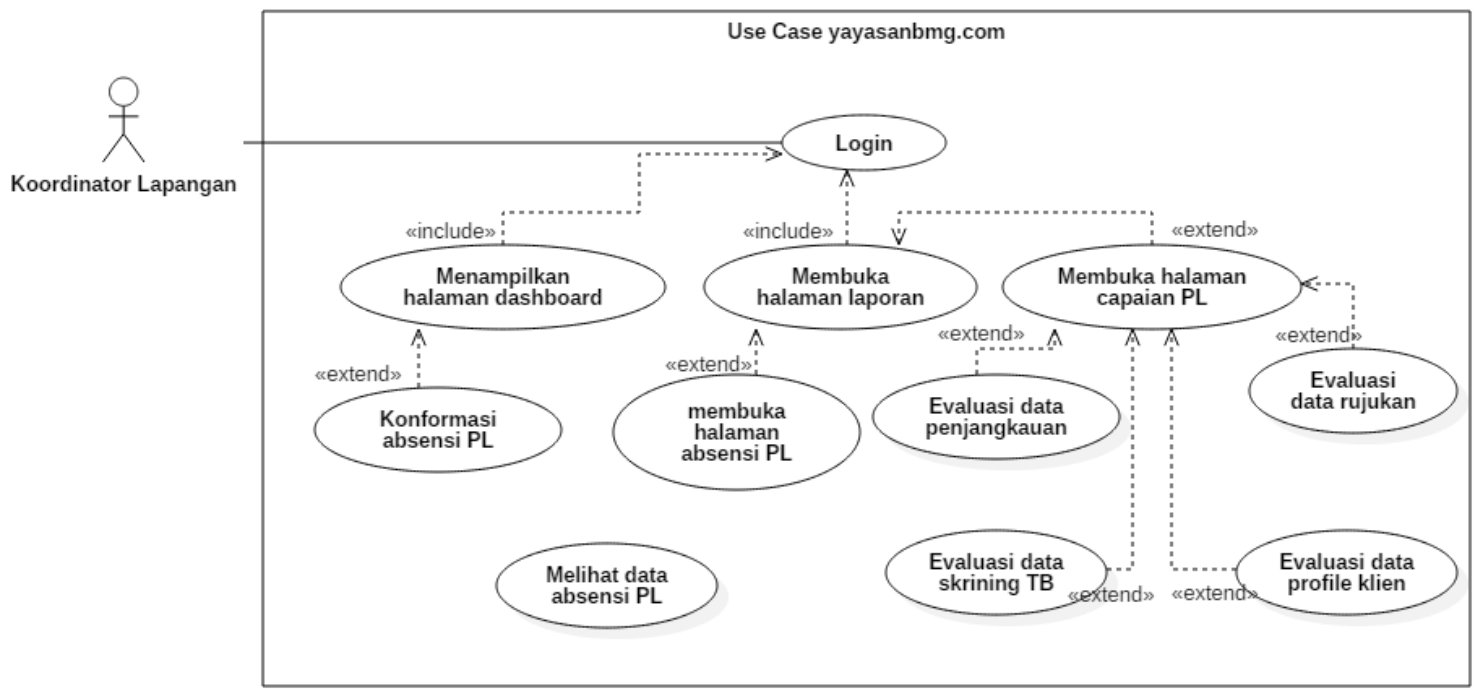




\subsubsection{Use Case Monev}

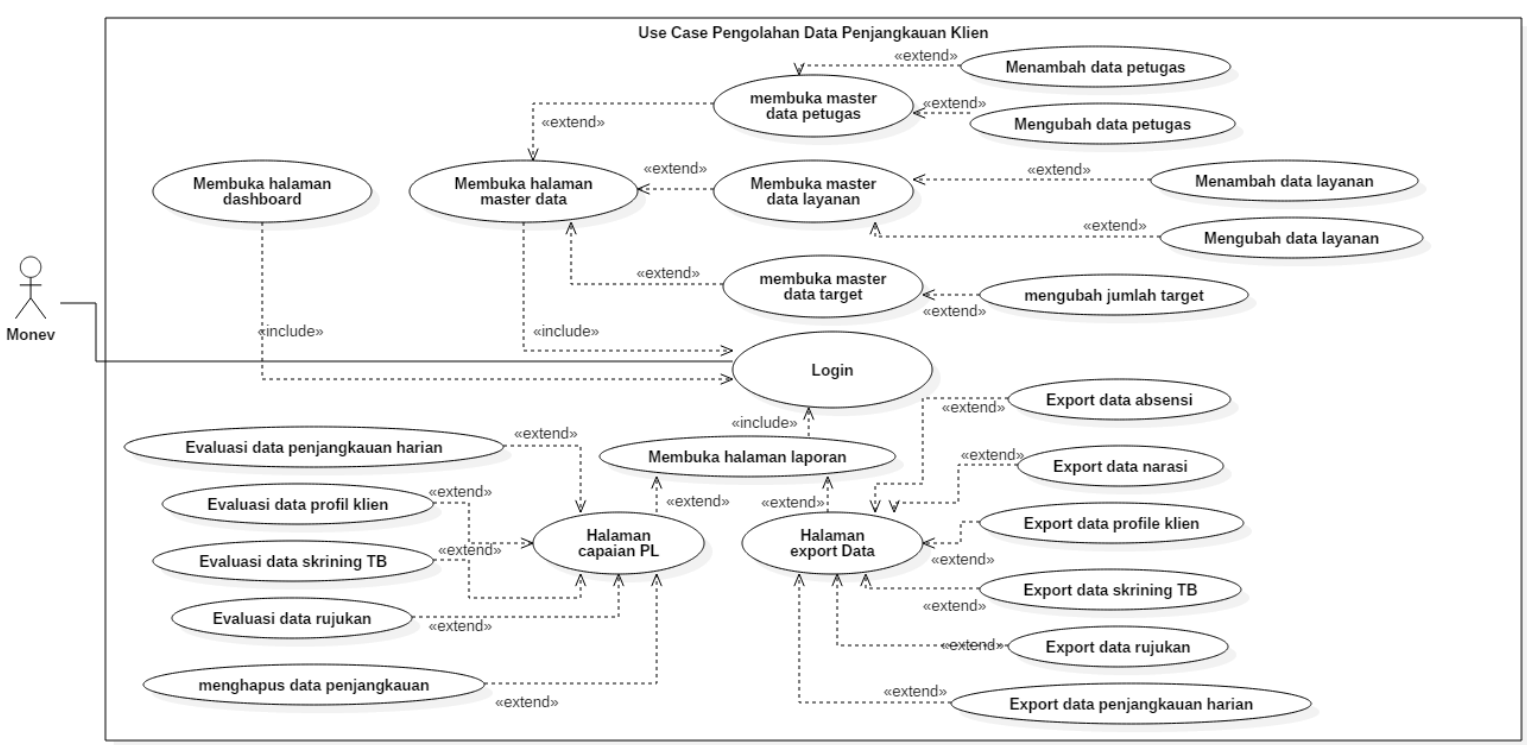

\subsubsection{Activity Diagram}

\subsubsection{Activity Diagram Field Officer (PL)}

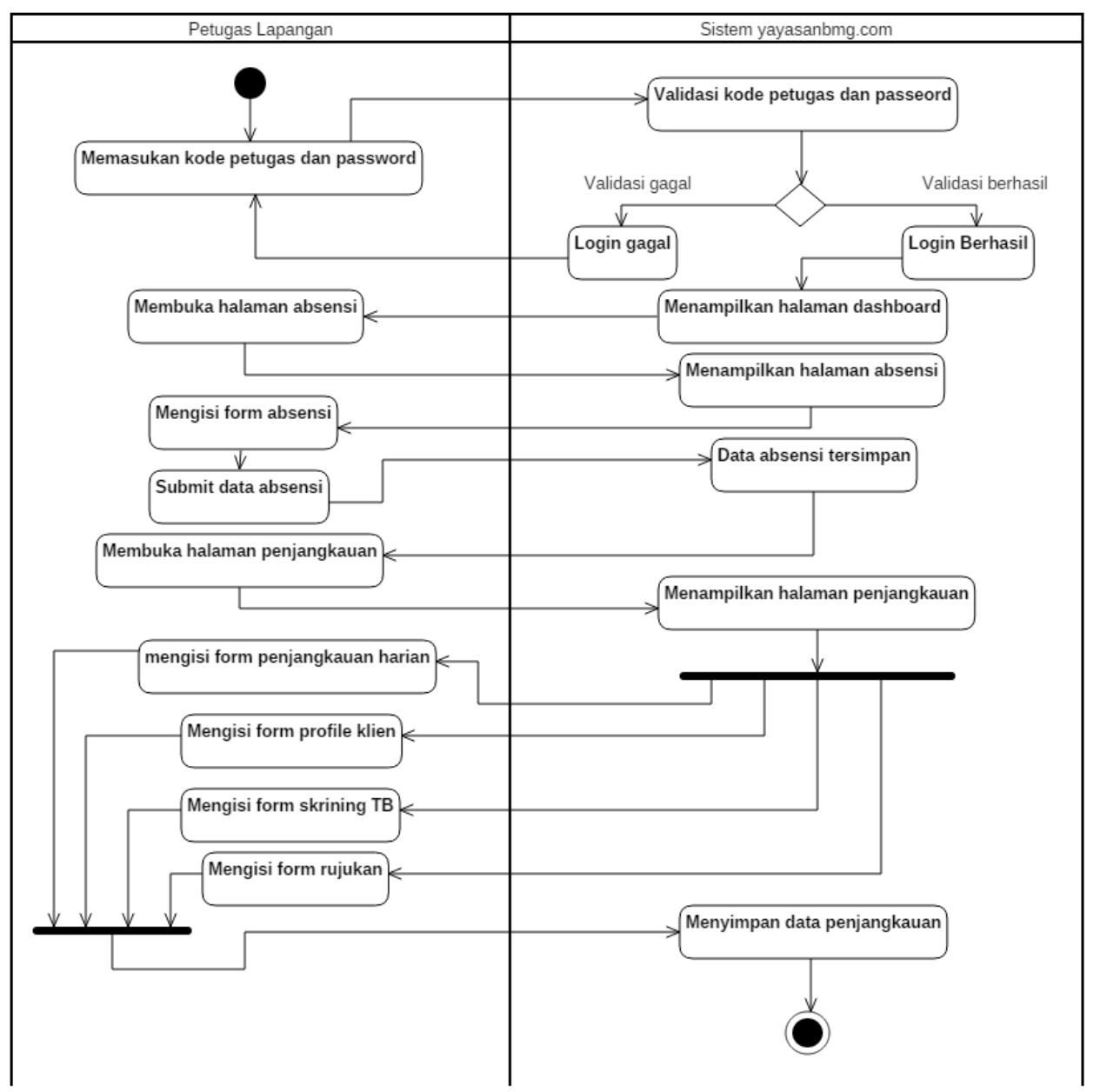




\subsubsection{Activity Diagram Coordinator Officer (KL)}

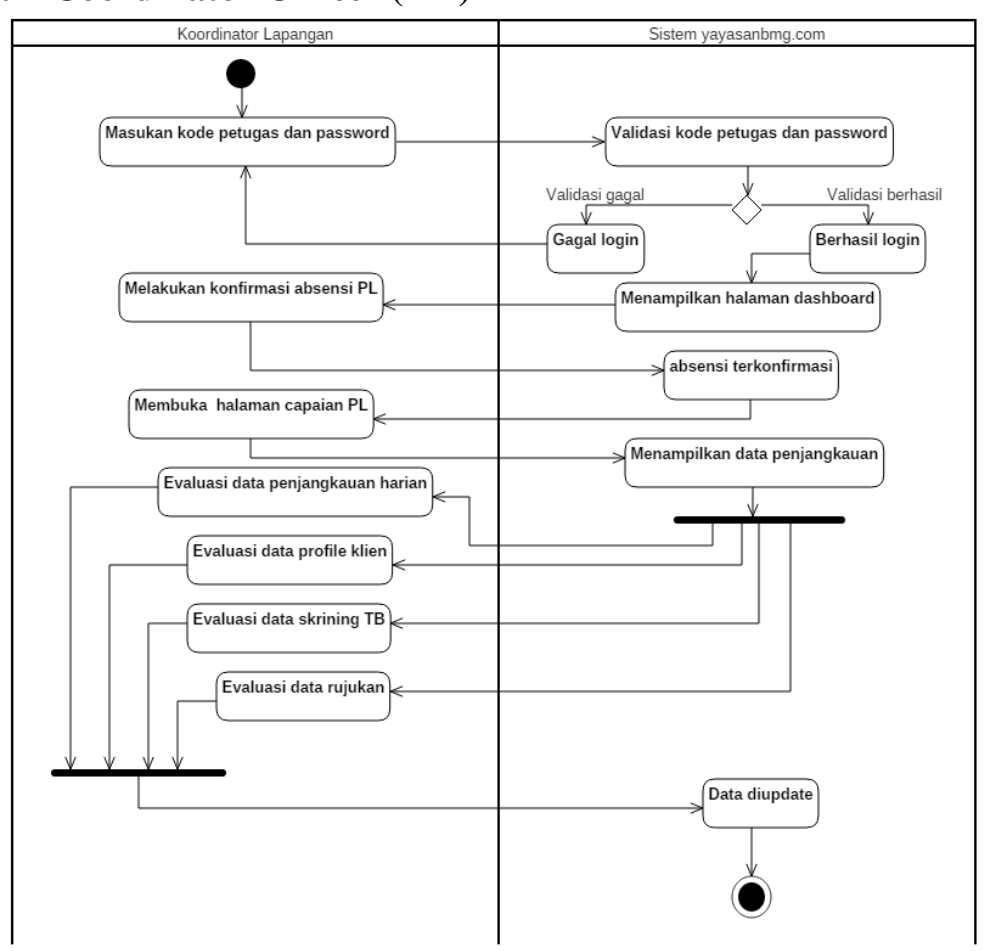

\subsubsection{Activity Diagram Monev}

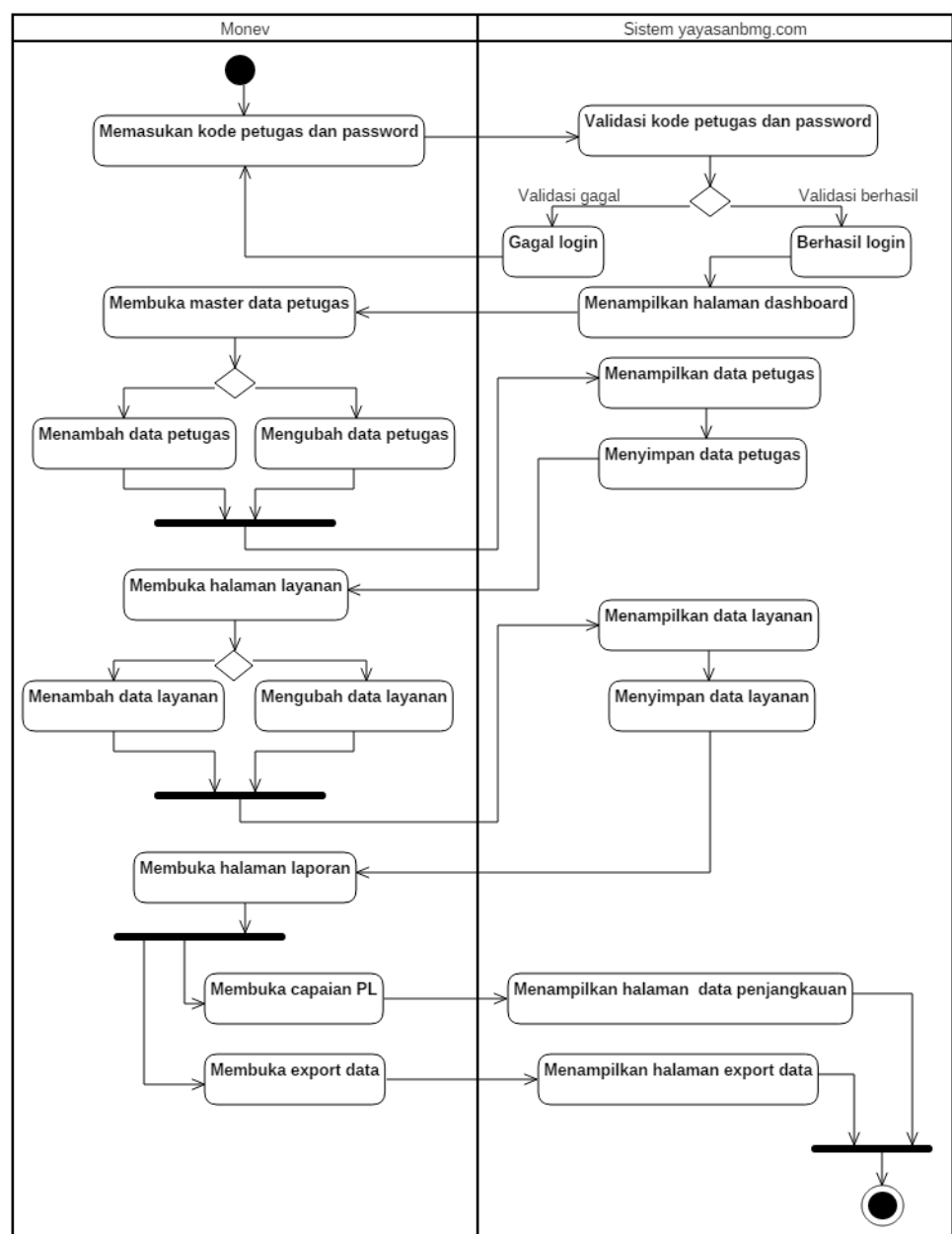




\subsection{Web Views}

The web display image below is taken from the web which is still in the form of localhost, not the web that is hosted because it is to maintain the confidentiality of the foundation's data.

\subsubsection{Login Page}

This is what the login page looks like. This login page is used to log in for all staff, from field staff, monev, peer educators, HSO and field coordinators:

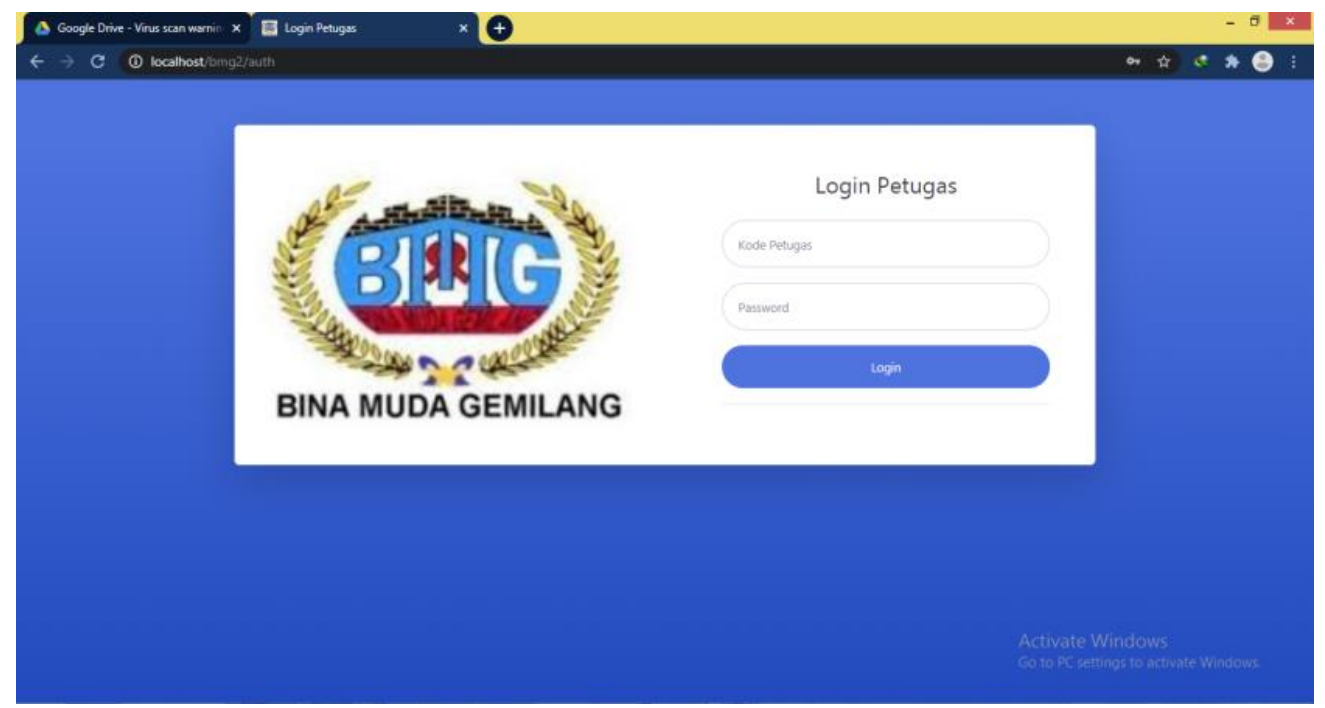

\subsubsection{User Dashboard Page (Field Officer)}

After successful login, the user will be directed according to their access rights. If those who $\log$ in are field officers, peer educators and HSO, they will be directed to the user page. And here is the user dashboard page:

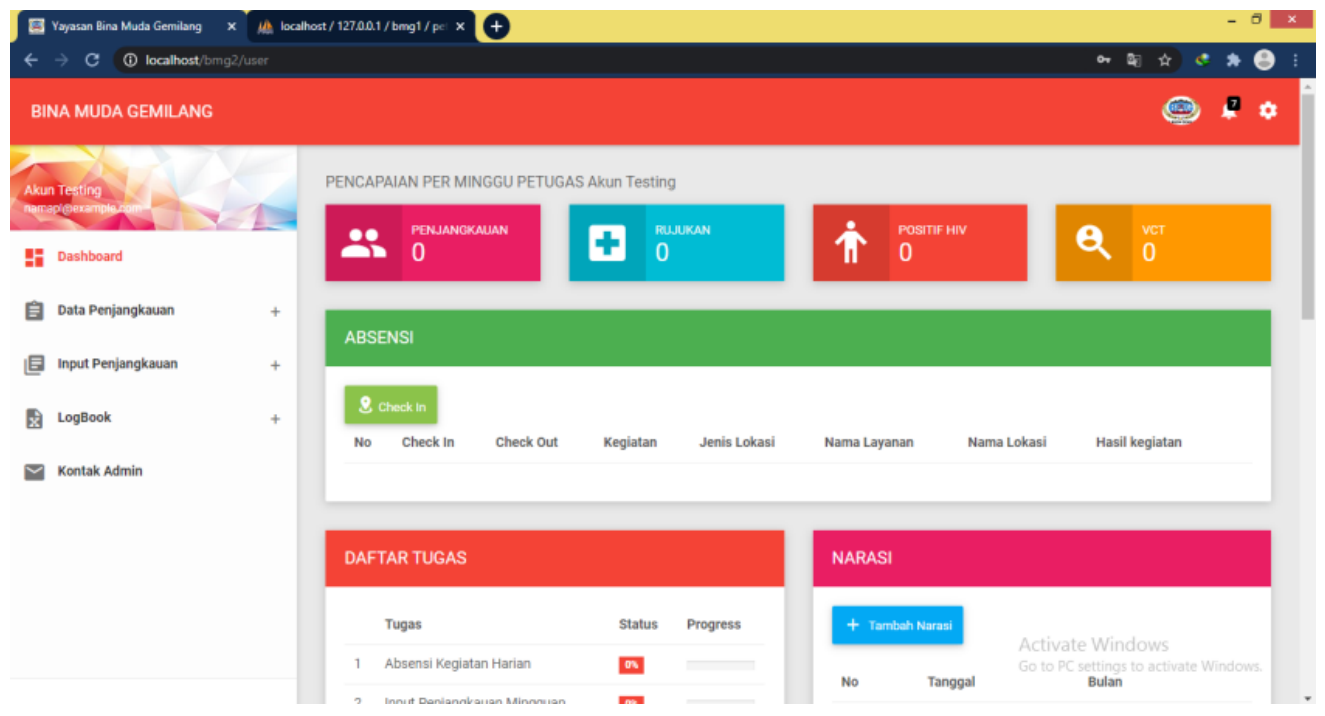

If the officer wants to do attendance, you can click the green checkin button in the attendance section on the dashboard page. 


\subsubsection{Attendance Page}

After clicking the check-in button, the field officer will be directed to the attendance page and must fill in the available data, accompanied by a photo of evidence of the activity with a watermark in the form of a timestamp and location to minimize cheating. Here's the attendance page:

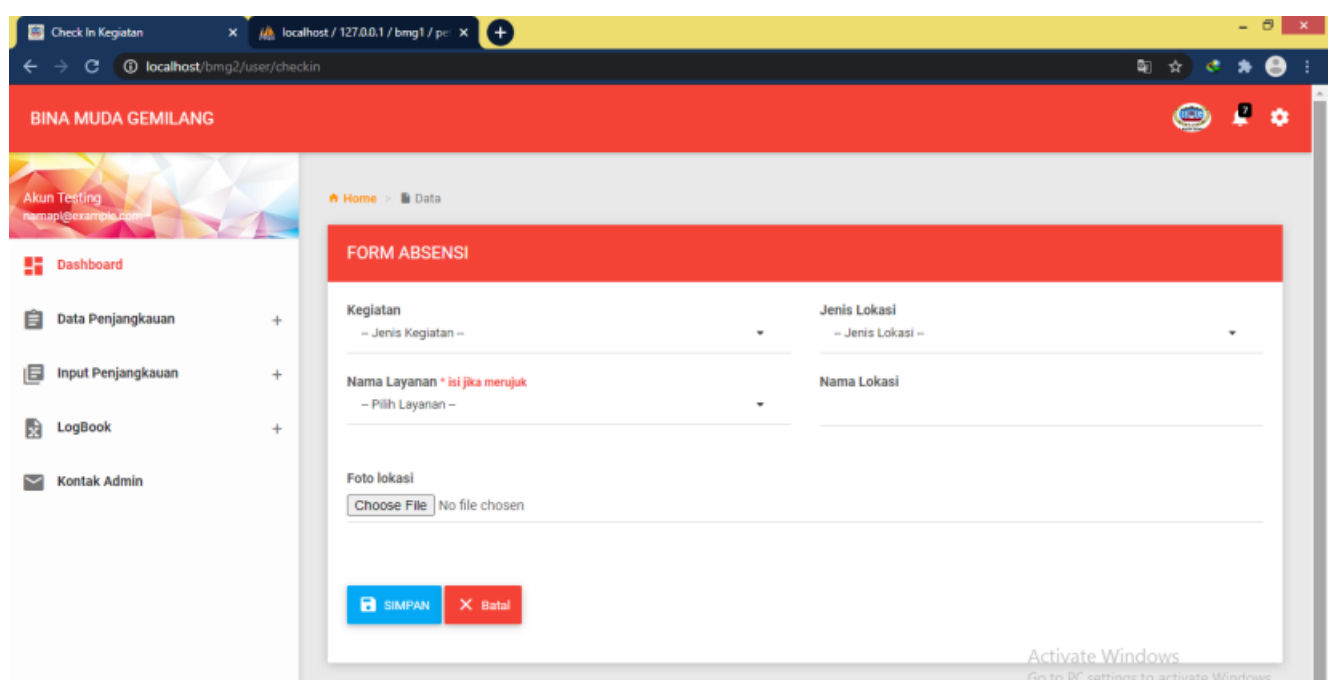

\subsubsection{Narrative Pages}

Here, officers who have access rights as a user can input a monthly narrative containing reports on their activities for a month. Fill in the form, there are challenges in the activity process, recommendations or suggestions from officers and follow-up plans.

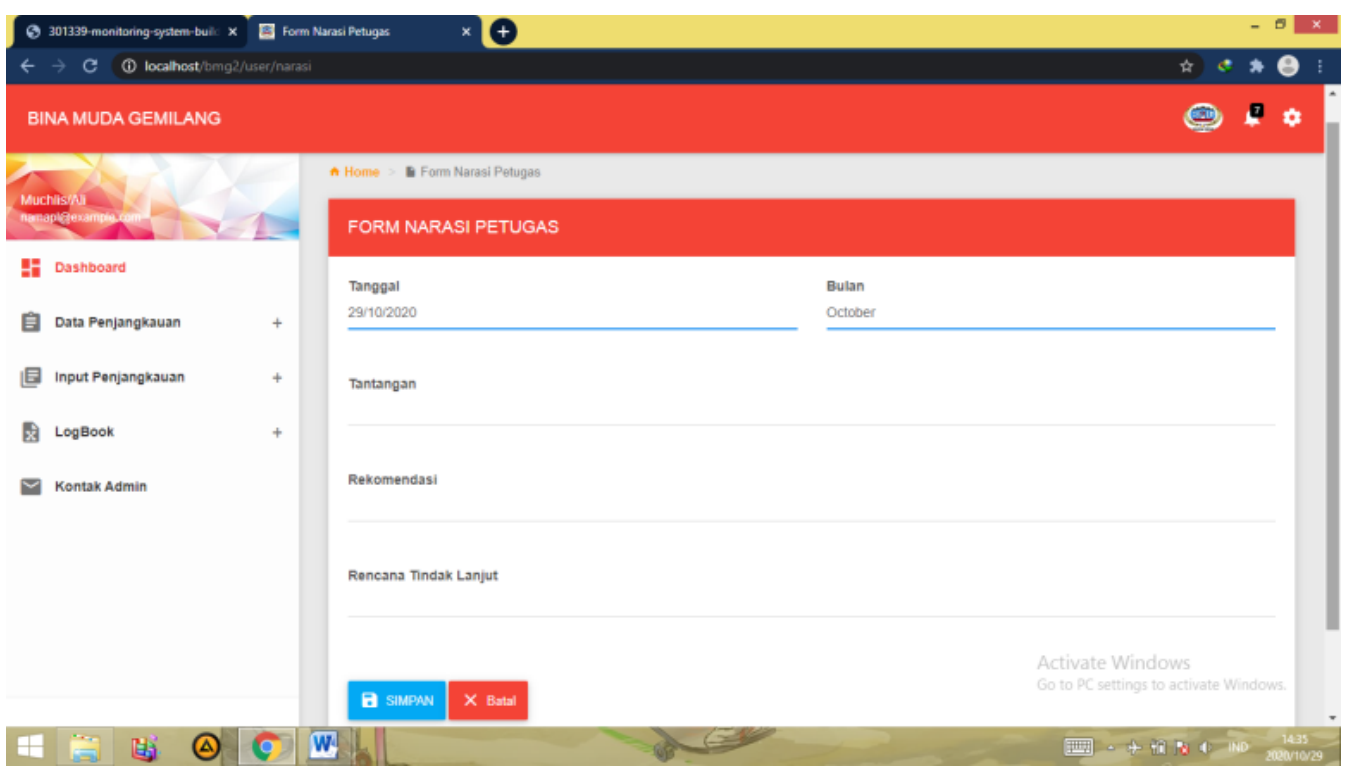

\subsubsection{Reference Pages}

This referral page will display client data that has been successfully referred to. However, the referral form input is carried out on the outreach page. 


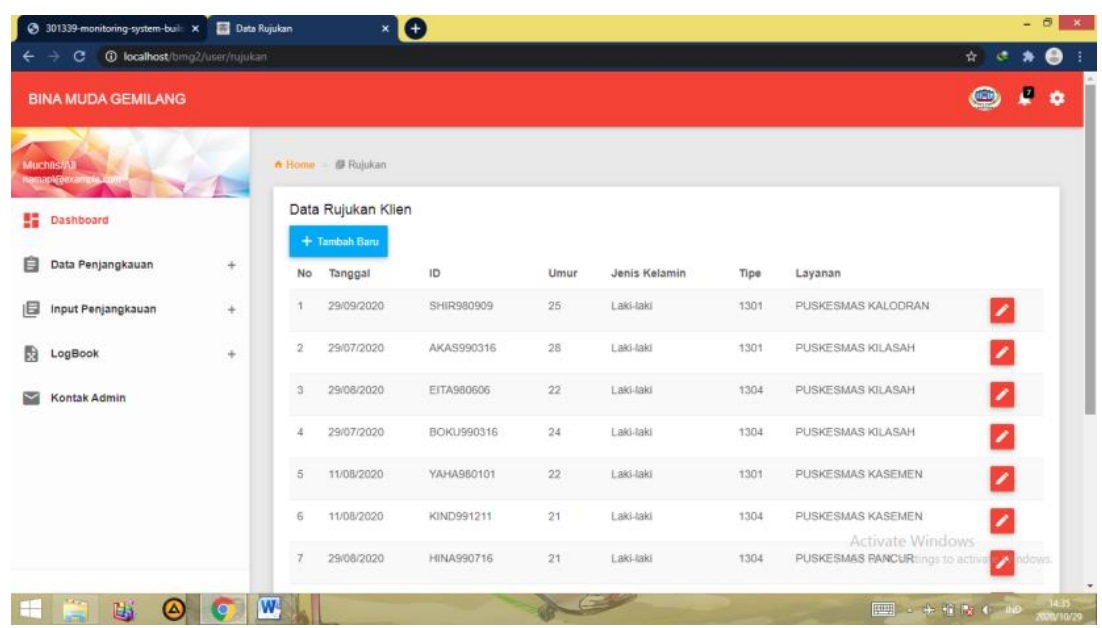

\subsubsection{Outreach page}

On this outreach page, field officers will input daily outreach data, client profiles, TB screening and referrals. The orange button means the data has not been completed, if it is green it means the data has been completed.

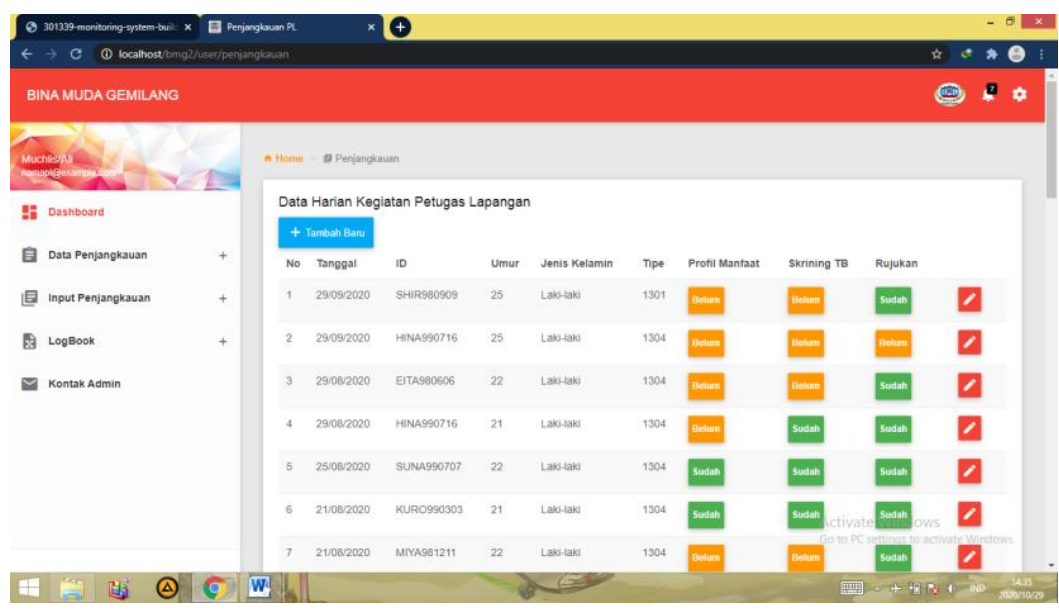

\subsubsection{Logbook page}

This logbook page is for export data into a CSV file containing client data that has been reached such as name, nik, telephone number and other personal data to be reached back in the next few months.

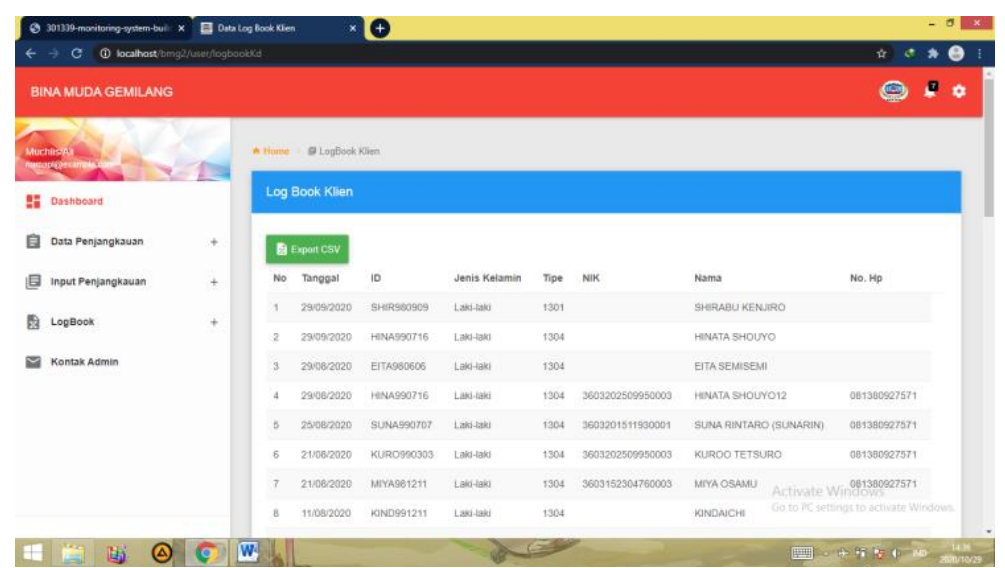




\subsubsection{KL Dashboard page}

And now go to the page for admin access rights for the KL (Field Coordinator) section. On the dashboard page, KL can see the achievement figures according to the intervention area. In addition, KL can also monitor outreach activities of PL (Field Officers) through their attendance.

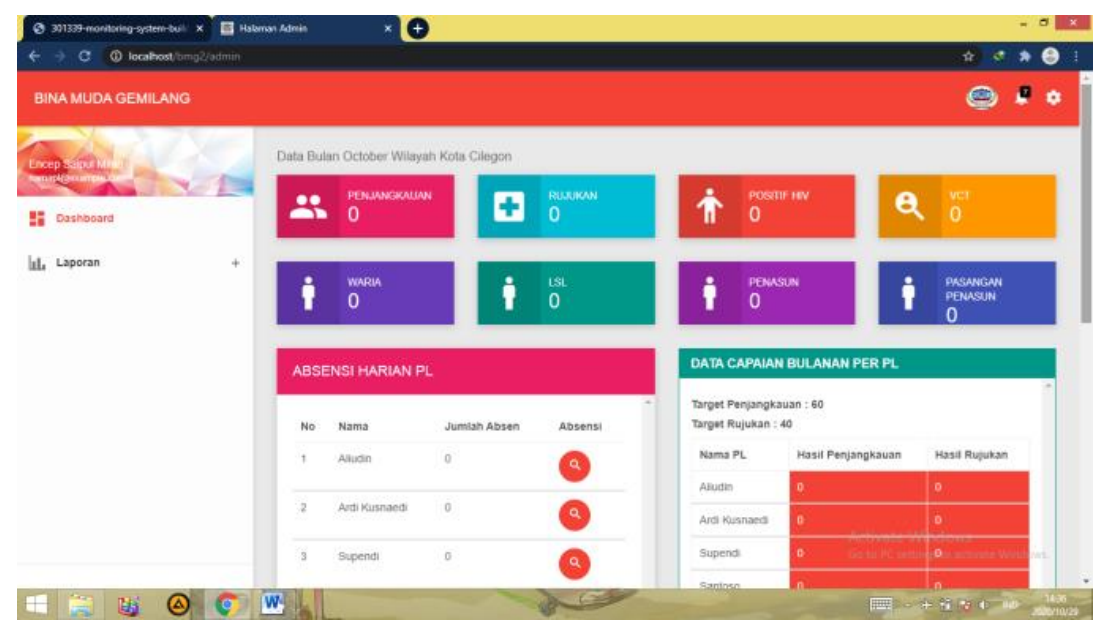

\subsubsection{PL Achievement Report Page}

On this page the KL conducts evaluation of outreach data such as daily outreach data, client profiles, TB screening and referrals. If there is inconsistent data, the KL can change the data. And if the data is in accordance, the KL will confirm the data that the data is valid.

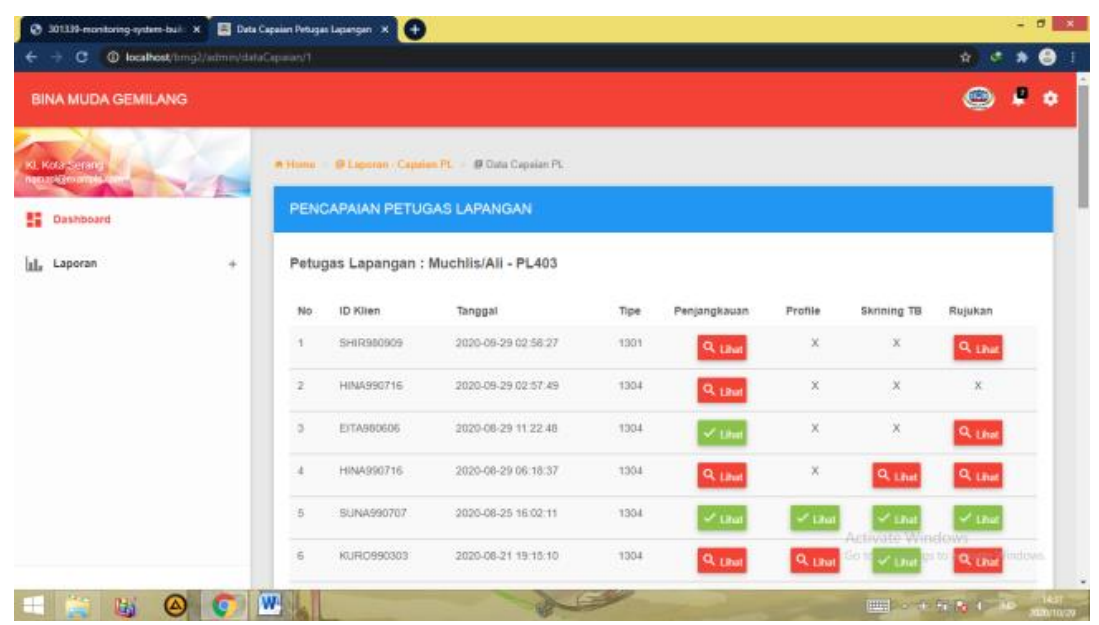

\subsubsection{PL Attendance Page}

The attendance data on the dashboard page is temporary, so the attendance data on the dashboard only displays the attendance data for that day. But on this PL attendance page all attendance data is displayed. 


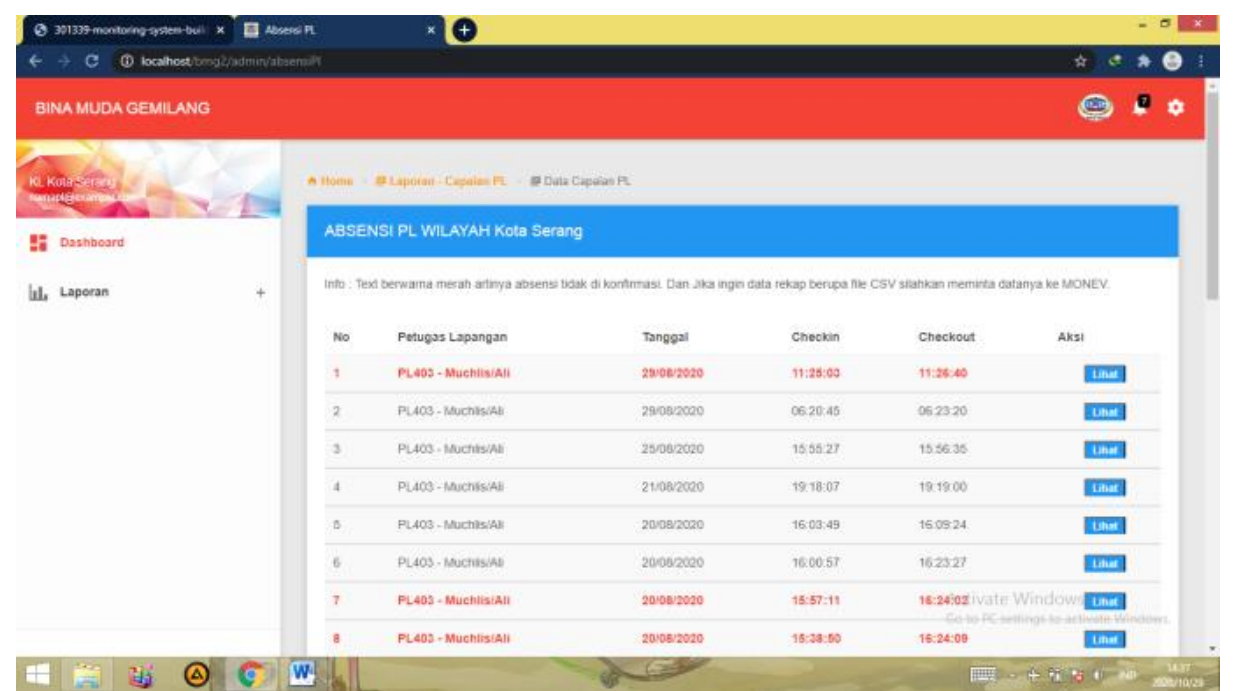

\subsubsection{Monev Dashboard page}

If when you log in using the monev code and password, you will be directed to the Movev dashboard page. On this page contains a lot of data in the form of reach and referral figures, the number of HIV positive cases, the percentage of PL achievements, the age range of clients and other data.

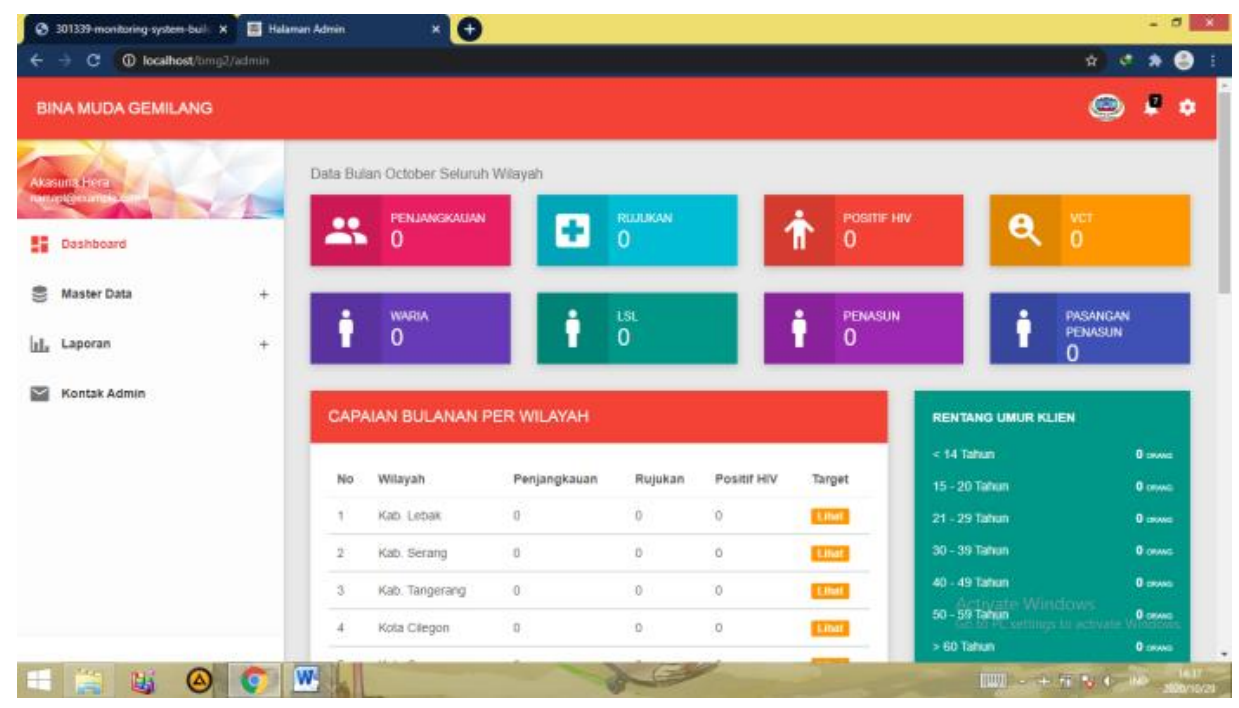

\subsubsection{Officer Master Data page}

On this page, monev can add and change officer data, be it field officers, field coordinators, HSOs and peer educators. 


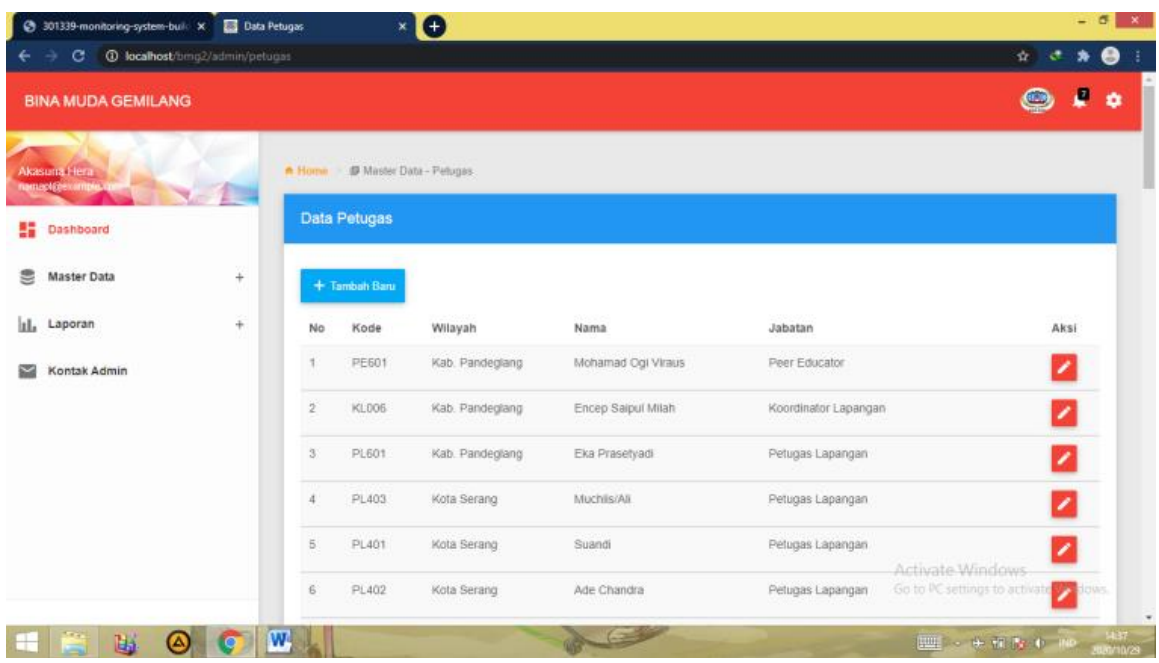

\subsubsection{Service Master Data page}

On this page, monev can add and change service data in the Banten area in the form of puskesmas services and public hospitals for making referrals.

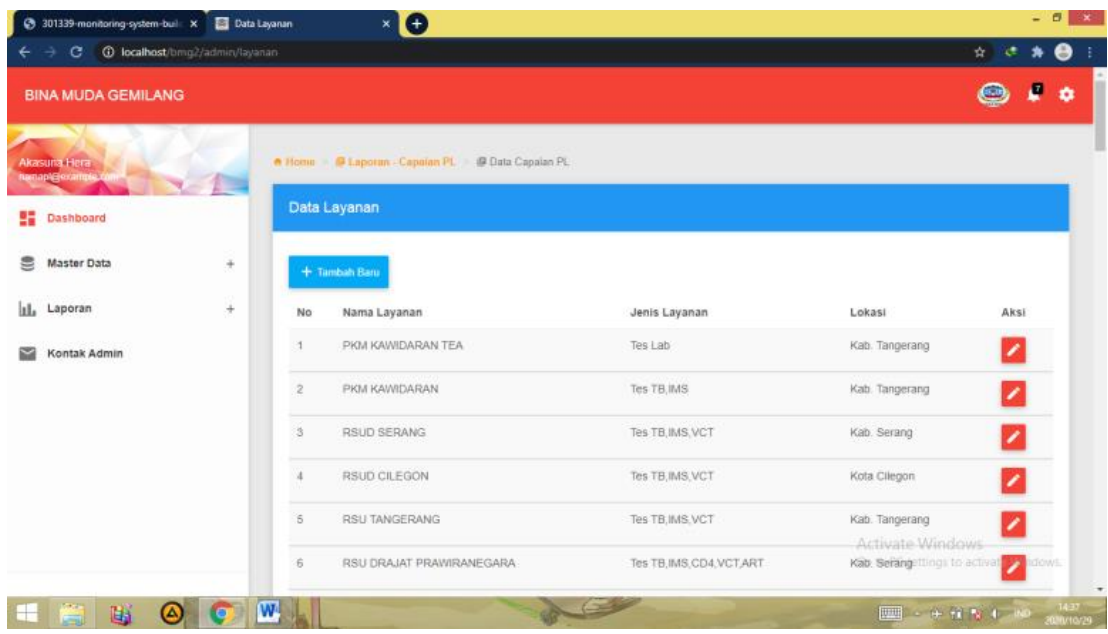

\subsubsection{Target Master Data Page}

On this page, monev can change the number of achievement targets according to existing categories. However, Monev cannot add to the target category, only the web admin can add it.

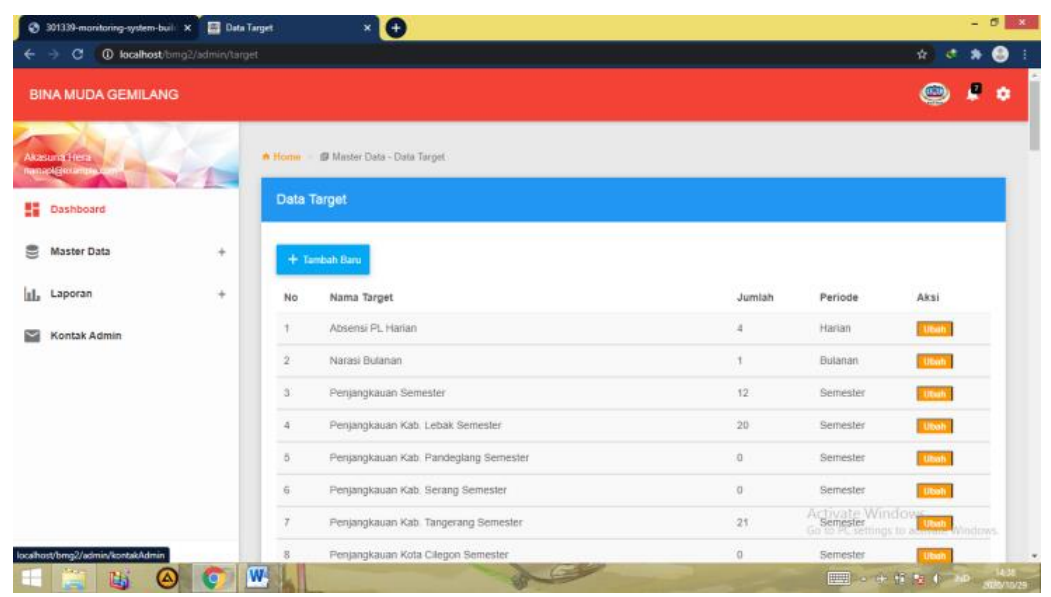




\subsubsection{PL Achievement Report Page}

This PL achievement report page is the same as the PL achievement page for the field coordinator. The difference is on the field coordinator page, the data displayed is only data in the intervention area. And if on the Monev page the data displayed is the data on the achievements of all the intervention areas.

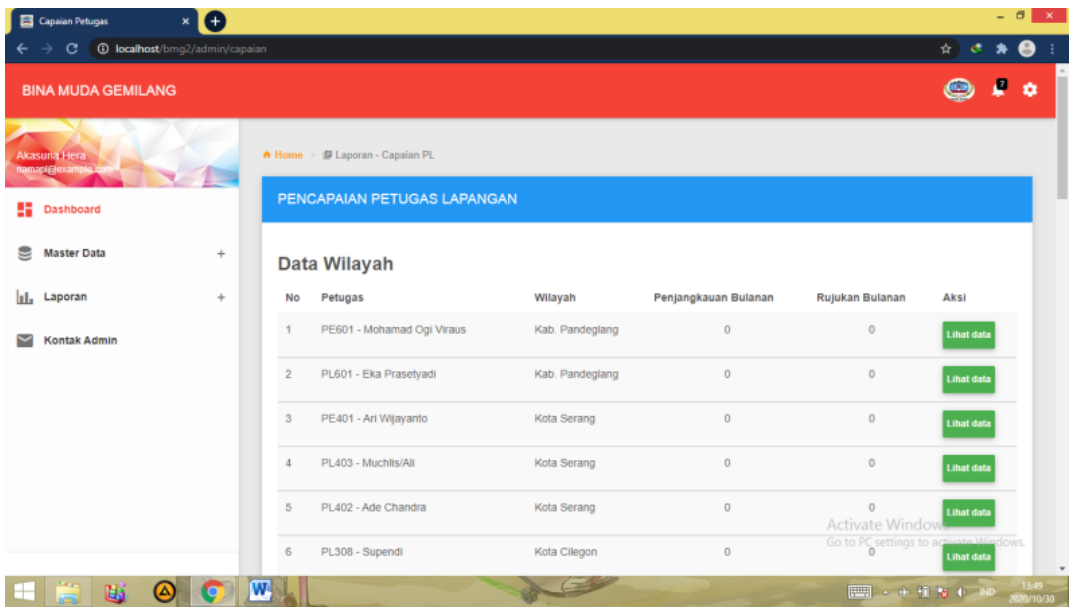

\subsubsection{Export Data page}

On the export data page, monev can export data such as daily outreach data, client profiles, TB screening, referrals, attendance, and narration to a CSV file.

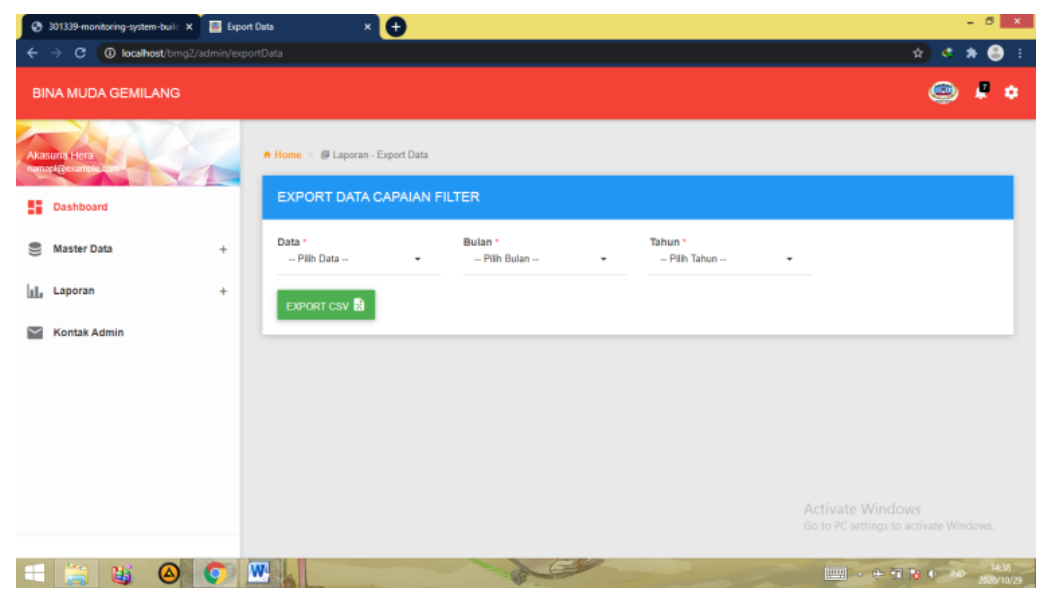

\section{CONCLUSION}

Based on research and analysis on the implementation of the outreach activity data processing system at the Bina Muda Gemilang Foundation, it can be concluded that:

1) In the previous outreach activity data processing system, there were still many gaps that resulted in a lot of data input errors and there was also no system that kept staff disciplined, so they often delayed inputting time.

2) The system's incompatibility with the needs also hinders the data processing process because the user needs more specific features that can facilitate data processing. In addition, this non-conforming system also affects data accuracy because it triggers data input errors and other errors. 
3) The data processing system for outreach activities created is based on user needs and field conditions of officers so that this system is deemed appropriate and facilitates business processes. In addition, this system can also minimize errors that often occur such as data input errors and data duplication due to a validation process when you want to save data, so that the level of data accuracy is better.

4) This system is proven to be able to increase the discipline of officers in data input, which previously the officers were always procrastinating and data accumulated at the end of the month due to the locking system of outreach dates so that officers could not delay data input.

\section{SUGGESTED}

Suggestions for further research are expected to have further developments regarding system security to prevent system breaches that can damage data and systems. Also optimization for data storage in the database and also optimization of functions and classes in the source code so that the web runs more optimally and does not consume a lot of memory and internet data.

\section{REFERENCES}

[1.] Hutahaean, J. (2015). “Konsep Sistem Informasi”. Yogyakarta: Deepublish.

[2.] Suryadi, Emi. "Sistem Pendukung Keputusan Pemilihan Kendaraan Dalam Mendistribusikan Zakat, Infak dan Sedekah". CCIT Journal, Vol. 9 No. 3, page 270.

[3.] Martono, Kartika dan Putri Aulia. 2017. "Aplikasi Jenjang Sosial Pendataan Kartu Keluarga Berbasis Web". CCIT Journal. Vol. 10 No. 2, August 2017

[4.] Desrianti, Dewi Immaniar dan Achmad Rizal Kurniawan. 2018. "Profile smk multimedia mandiri melalui websile sebagai peunjang media informasi" ICIT Journal, vol. 4, no. 1, pp. 41-51.

[5.] Sahar Hasan \& Asghar, D. M. (2015). "Web-based Attendance Management System. ResearchGate", 8. 